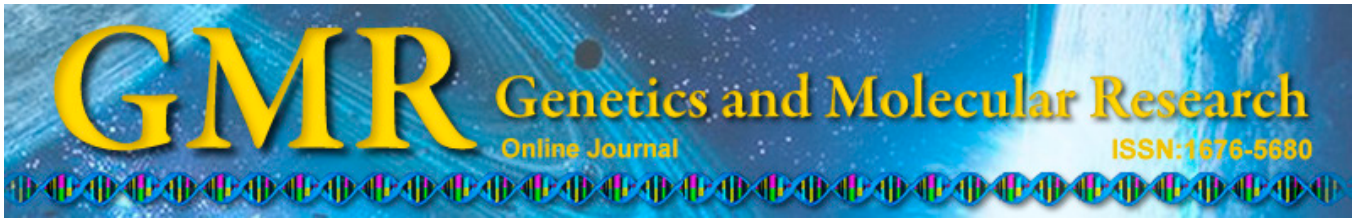

\title{
Molecular characterization of bromeliads from northeast Brazil
}

\author{
S.D. Vieira ${ }^{1}$, A.R.C. Rabbani ${ }^{1}$, F. Santos ${ }^{1}$, R. Silva-Mann', \\ M.F. Arrigoni-Blank ${ }^{1}$, A.P.N. Prata ${ }^{2}$, L.V. Resende ${ }^{3}$, M. Pasqual ${ }^{3}$ \\ and A.F. Blank ${ }^{1}$ \\ ${ }^{1}$ Laboratório de Cultura de Tecidos e Melhoramento Vegetal, \\ Departamento de Engenharia Agronômica, Universidade Federal de Sergipe, \\ São Cristóvão, SE, Brasil \\ ${ }^{2}$ Herbário ASE, Departamento de Biologia, Universidade Federal de Sergipe, \\ São Cristóvão, SE, Brasil \\ ${ }^{3}$ Laboratório de Cultura de Tecidos, Departamento de Agricultura, \\ Universidade Federal de Lavras, Lavras, MG, Brasil \\ Corresponding author: A.F. Blank \\ E-mail: afblank@ufs.br
}

Genet. Mol. Res. 13 (4): 9851-9860 (2014)

Received February 17, 2014

Accepted May 27, 2014

Published November 27, 2014

DOI http://dx.doi.org/10.4238/2014.November.27.12

\begin{abstract}
Bromeliaceae is an important botany family that includes many species with economic value; demand for members of this family is increasing. However, illegal collection frequently occurs, drastically reducing the species populations; thus, it is necessary to collect and store Bromeliaceae genetic material. In this study, we identified and quantified genetic variability of the Bromeliad family using dominant markers to create the first Germplasm Bank in the northeast region of Brazil. Molecular tools were used to characterize the collected accessions. The combination of 11 inter-simple sequence repeats and 13 random amplified polymorphic DNA markers were used to detect the genetic variability of wild bromeliad accessions.
\end{abstract}

Key words: Bromeliad differentiation; Endangered species; Molecular method 


\section{INTRODUCTION}

Bromeliads are plants that belong to the Bromeliaceae family, which includes approximately 60 genera and 3170 species (Luther, 2008). These species are perennial plants with a wide variety of shapes, colors, and sizes. The plants are present in the tropics of North to South America, with only 1 species in Africa (Benzing, 2000). Bromeliads have 3 growth habits: rupiculous, terricolous, and epiphytic. The plants exhibit adaptive mechanisms, such as reduced root size and function as well as pollination and seed-dispersal strategies under various environmental conditions.

Plants in the Bromeliaceae family are widely used for decoration and landscaping projects due to their inflorescence, which has multiple colors that remains bright for weeks because of the beauty of their leaves. Because of their popularity, bromeliad removal from natural environments has contributed to decreased genetic variability within several species (Coffani-Nunes, 2002).

Genetic diversity is important because it allows species to respond to environmental change: genetic diversity functions as a resource for adaptation, allowing survival over time (Sheng et al., 2005), and should thus be conserved. For the decrease in plant genetic resources, the main concern for breeders is genetic drift or the loss of genetic diversity within aspecies, restricting the species' genetic base. A severe population bottleneck results in vulnerability, which can only be avoided by increasing variability based on the available genetic resources, i.e., the germplasm of the species.

One method of conserving genetic variability is by collecting plant material to establish germplasm banks. Such collection procedures seek to identify and obtain a representative sampling of genetic variation in a species' gene pool to preserve genetic variability (Morales et al., 1996). The main reason for establishing and maintaining a germplasm bank is to store individuals that can be used to examine a particular accession as well as to identify important traits for genetic plant-breeding programs (Carvalho and Quesenberry, 2009).

Genetic variability can be measured using several methods to infer evolutionary processes in the ecological history of species and variations in the distribution of populations. In this context, molecular markers are widely used for studying genetic variability (Handa, 1998). The characterization and differentiation within and among bromeliads have not been conducted; additionally, molecular markers have not been used to characterize wild genotypes of this species in northeast Brazil. The aim of this study was to identify and quantify the genetic variability of the bromeliad family using inter-simple sequence repeats (ISSR) and random amplified polymorphic DNA (RAPD) markers and to create the first active germplasm bank in northeast Brazil.

\section{MATERIAL AND METHODS}

An exploratory study was carried out in areas containing populations of bromeliad species in the State of Sergipe. Subsequently, expeditions to municipalities in the state were conducted (Figure 1). Mapping was performed at all studied locations using a global positioning system (Garmin, Schaffhausen, Switzerland).

Seeds were collected from individual plants when available. Collected specimens were labeled and used to create the active germplasm bank in a greenhouse at the Department of Agronomical Engineering at the Universidade Federal of Sergipe. An earthworm compost 
and coconut coir (1:1) mixture was used as substrate, and the pot size chosen based on the specimen size. Accessions were identified by the ASE Herbarium of the university (Table 1).

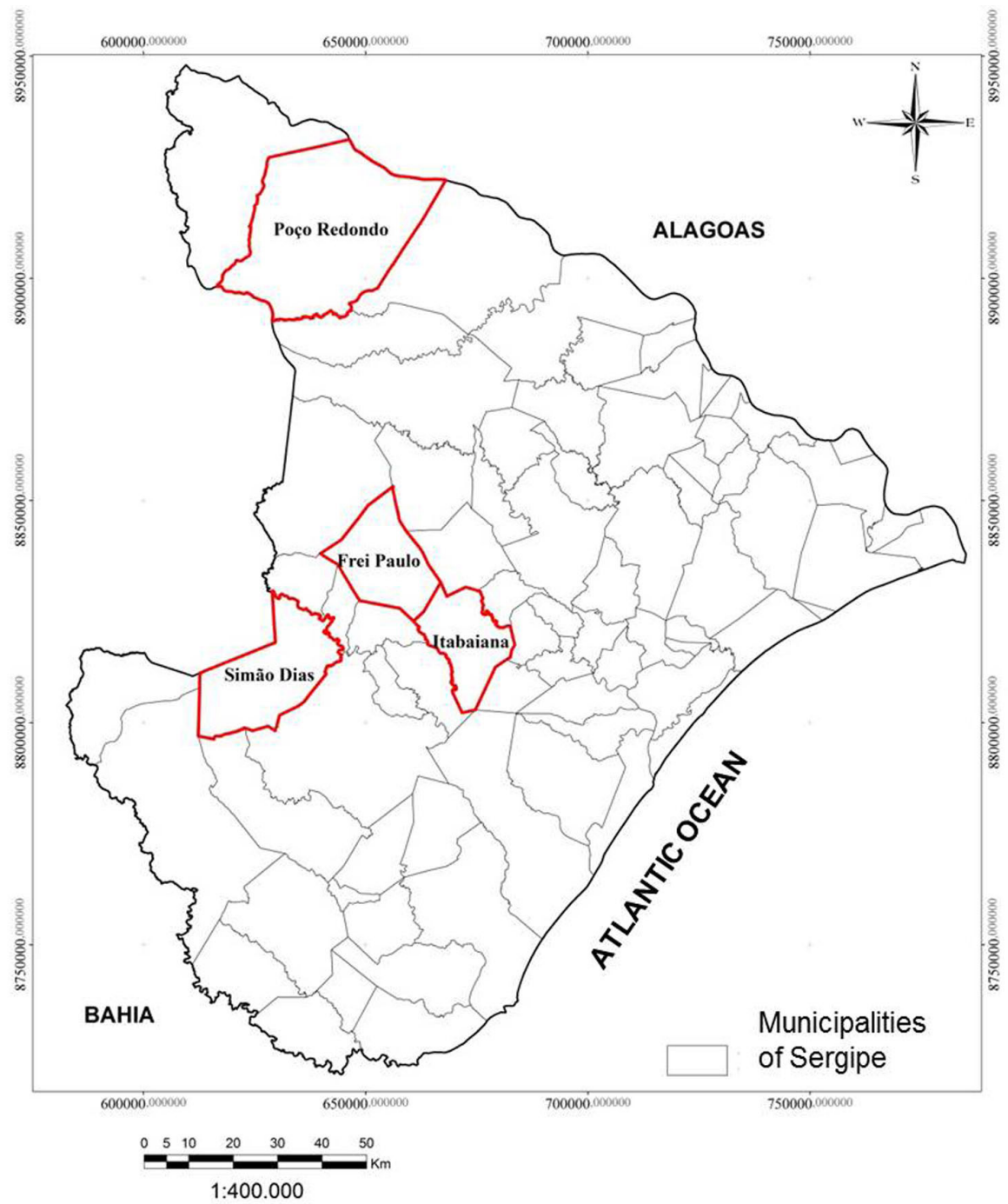

Figure 1. Map of the Sergipe State showing the regions from which bromeliad accessions were collected.

Table 1. Sergipe municipalities and the number of bromeliad accessions collected.

\begin{tabular}{lc}
\hline Municipality & Number of specimens \\
\hline Poço Redondo & 1 \\
Frei Paulo & 6 \\
Simão Dias & 8 \\
Itabaiana & 19 \\
\hline
\end{tabular}


DNA was isolated from young leaves as described by Doyle and Doyle (1991). A total of 24 primers, 11 ISSR from Operon (Operon Technologies, Alameda, CA, USA) (01, 808, $810,812,827,834,842,855,866,888,841$ ) and 13 RAPD (IDT01, IDT02, IDT09, IDT10, IDT12, IDT13, IDT14, IDT15, IDT16, IDT17, IDT18, IDT19, IDT20) from Integrated DNA Technologies (Coralville, IA, USA) (Table 2) were used for genetic diversity screening (Table 3). Polymerase chain reaction (PCR) amplifications were performed using an Axygen thermocycler (Maxygene Gradient Thermal Cycler, AxygenBiosciences, Union City, CA, USA) with a cycle comprising $94^{\circ} \mathrm{C}$ for 2 min for initial denaturation, followed by 35 cycles of denaturation at $94^{\circ} \mathrm{C}$ for $15 \mathrm{~s}, 36^{\circ} \mathrm{C}$ for $30 \mathrm{~s}$ for primer annealing, $72^{\circ} \mathrm{C}$ for $30 \mathrm{~s}$ for extension, and 1 cycle of $72^{\circ} \mathrm{C}$ for $2 \mathrm{~min}$ for final extension.

\begin{tabular}{|c|c|}
\hline Primer & Sequence $\left(5^{\prime}-3^{\prime}\right)$ \\
\hline \multicolumn{2}{|l|}{ ISSR } \\
\hline 01 & ACA CAC ACA CAC ACA CT \\
\hline 808 & AGA GAG AGA GAG AGA GC \\
\hline 810 & GAG AGA GAG AGA GAG AT \\
\hline 812 & GAG AGA GAG AGA GAG AA \\
\hline 827 & ACA CAC ACA CAC ACA CG \\
\hline 834 & AGA GAG AGA GAG AGA GYT \\
\hline 842 & GAG AGA GAG AGA GAG AYG \\
\hline 855 & ACA CAC ACA CAC ACA CYT \\
\hline 866 & СТС СТССТССТССТССТC \\
\hline 888 & BDB CAC ACA CAC ACA CA \\
\hline 891 & HVH TGT GTG TGT GTG TG \\
\hline \multicolumn{2}{|l|}{ RAPD } \\
\hline IDT01 & CAG GCC CTT C \\
\hline IDT02 & TGC CGA GCT G \\
\hline IDT09 & CCC AAG GTC C \\
\hline IDT10 & GGT GCG GGA A \\
\hline IDT12 & GAG GAT CCC T \\
\hline IDT13 & CTA CGG AGG A \\
\hline IDT14 & GGC ACT GAG G \\
\hline IDT15 & GGT CGG AGA A \\
\hline IDT16 & TCG GAC GTG A \\
\hline IDT17 & ACC TGG ACA C \\
\hline IDT18 & GGA GGA GAG G \\
\hline IDT19 & CCC GGC ATA A \\
\hline IDT20 & AAA GTT GGG A \\
\hline
\end{tabular}

Fragments were visualized on a $1.5 \%$ agarose gel. The gel was stained with Gel Red (Biotium, Hayward, CA, USA). ISSR and RAPD amplification products were visualized under ultraviolet light using an imaging system.

ISSR and RAPD markers were scored based on the presence (1) or absence (0) of the marker. The bootstrap method was applied to estimate variance in genetic distance and was obtained from 5000 bootstrap random draws using the DBOOT software (Coelho, 2000). A data matrix was generated and similarity coefficients were calculated using Jaccard's index (Jaccard, 1908). A dendrogram was constructed using the unweighted pair group method with arithmetic mean cluster algorithm using the Free Tree software (Hampl et al., 2001) and TreeView (Page, 1996) for visualization.

\section{RESULTS}

We identified 34 accessions (Table 4 ). The 24 primers generated a total of 416 polymorphic fragments (370 from ISSR and 46 from RAPD markers). 
Table 3. Bromeliad accessions collected in the Sergipe State.

\begin{tabular}{|c|c|c|c|c|}
\hline ID & Subfamily & Municipality & Geographic coordinates & \\
\hline I_Vsp1 (BRO-004) & Tillandsioideae & Itabaiana & $10^{\circ} 42^{\prime} 36.5^{\prime \prime} \mathrm{S}$ & $37^{\circ} 49^{\prime} 38.3^{\prime \prime} \mathrm{W}$ \\
\hline I_Tbulbosa (BRO-008) & Tillandsioideae & Itabaiana & $10^{\circ} 44^{\prime} 35.6^{\prime \prime} \mathrm{S}$ & $37^{\circ} 21^{\prime} 56.1^{\prime \prime} \mathrm{W}$ \\
\hline I_Vsp2 (BRO-009) & Tillandsioideae & Itabaiana & $10^{\circ} 42^{\prime} 38.8^{\prime \prime} \mathrm{S}$ & $37^{\circ} 49^{\prime} 40.6^{\prime \prime} \mathrm{W}$ \\
\hline I_Tpolistachia1 (BRO-019) & Tillandsioideae & Itabaiana & $10^{\circ} 42^{\prime} 38.4^{\prime \prime} \mathrm{S}$ & $37^{\circ} 49^{\prime} 23.7^{\prime \prime} \mathrm{W}$ \\
\hline I_Amultiflora1 (BRO-016) & Bromelioideae & Itabaiana & $10^{\circ} 45^{\prime} 29.9^{\prime \prime} \mathrm{S}$ & $37^{\circ} 20^{\prime} 30.4^{\prime \prime} \mathrm{W}$ \\
\hline I_Amultiflora2 (BRO-017) & Bromelioideae & Itabaiana & $10^{\circ} 45^{\prime} 28.8^{\prime \prime} \mathrm{S}$ & $37^{\circ} 20^{\prime} 32.9^{\prime \prime} \mathrm{W}$ \\
\hline I_Tpolistachia2 (BRO-012) & Tillandsioideae & Itabaiana & $10^{\circ} 49^{\prime} 33.0^{\prime \prime} \mathrm{S}$ & $37^{\circ} 26^{\prime} 24.0^{\prime \prime} \mathrm{W}$ \\
\hline I_Vsp3 (BRO-020) & Tillandsioideae & Itabaiana & $10^{\circ} 42^{\prime} 41.6^{\prime \prime} \mathrm{S}$ & $37^{\circ} 49^{\prime} 43.3^{\prime \prime} \mathrm{W}$ \\
\hline I_Vsp4 (BRO-021) & Tillandsioideae & Itabaiana & $10^{\circ} 42^{\prime} 40.2^{\prime \prime} \mathrm{S}$ & $37^{\circ} 49^{\prime} 49.3^{\prime \prime} \mathrm{W}$ \\
\hline I_Tpolistachia3 (BRO-022) & Tillandsioideae & Itabaiana & $10^{\circ} 42^{\prime} 38.5^{\prime \prime} \mathrm{S}$ & $37^{\circ} 49^{\prime} 23.6^{\prime \prime} \mathrm{W}$ \\
\hline I_Aaquilega1 (BRO-024) & Bromelioideae & Itabaiana & $10^{\circ} 45^{\prime} 29.9^{\prime \prime} \mathrm{S}$ & $37^{\circ} 20^{\prime} 30.4^{\prime \prime} \mathrm{W}$ \\
\hline I_Tpolistachia4 (BRO-031) & Tillandsioideae & Itabaiana & $10^{\circ} 42^{\prime} 35.1^{\prime \prime} \mathrm{S}$ & $37^{\circ} 49^{\prime} 31.8^{\prime \prime} \mathrm{W}$ \\
\hline I_Amultiflora3 (BRO-036) & Bromelioideae & Itabaiana & $10^{\circ} 45^{\prime} 29.9^{\prime \prime} \mathrm{S}$ & $37^{\circ} 20^{\prime} 30.4^{\prime \prime} \mathrm{W}$ \\
\hline I_Anudicaulis1 (BRO-049) & Bromelioideae & Itabaiana & $10^{\circ} 45^{\prime} 25.4^{\prime \prime} \mathrm{S}$ & $37^{\circ} 20^{\prime} 29.5^{\prime \prime} \mathrm{W}$ \\
\hline I_Vscalari (BRO-052) & Tillandsioideae & Itabaiana & $10^{\circ} 42^{\prime} 35.2^{\prime \prime} \mathrm{S}$ & $37^{\circ} 49^{\prime} 33.9^{\prime \prime} \mathrm{W}$ \\
\hline I_Vsp5 (BRO-057) & Tillandsioideae & Itabaiana & $10^{\circ} 42^{\prime} 40.2^{\prime \prime} \mathrm{S}$ & $37^{\circ} 49^{\prime} 49.3^{\prime \prime} \mathrm{W}$ \\
\hline I_Anudicaulis2 (BRO-061) & Bromelioideae & Itabaiana & $10^{\circ} 45^{\prime} 19.9^{\prime \prime} \mathrm{S}$ & $37^{\circ} 20^{\prime} 31.9^{\prime \prime} \mathrm{W}$ \\
\hline I_Anudicaulis3 (BRO-065) & Bromelioideae & Itabaiana & $10^{\circ} 45^{\prime} 19.9^{\prime \prime} \mathrm{S}$ & $37^{\circ} 20^{\prime} 31.9^{\prime \prime} \mathrm{W}$ \\
\hline I_Tgardineri (BRO-096) & Tillandsioideae & Itabaiana & $10^{\circ} 45^{\prime} 39.9^{\prime \prime} \mathrm{S}$ & $37^{\circ} 20^{\prime} 24.1^{\prime \prime} \mathrm{W}$ \\
\hline SD_Asp1 (BRO-108) & Bromelioideae & Simão Dias & $10^{\circ} 42^{\prime} 40.2^{\prime \prime} \mathrm{S}$ & $37^{\circ} 49^{\prime} 49.3^{\prime \prime} \mathrm{W}$ \\
\hline SD_Vsp1 (BRO-111) & Tillandsioideae & Simão Dias & $10^{\circ} 35^{\prime} 1.40^{\prime \prime} \mathrm{S}$ & $37^{\circ} 34^{\prime} 2.00^{\prime \prime} \mathrm{W}$ \\
\hline SD_Vsp2 (BRO-112) & Tillandsioideae & Simão Dias & $10^{\circ} 35^{\prime} 3.70^{\prime \prime} \mathrm{S}$ & $37^{\circ} 34^{\prime} 6.00^{\prime \prime} \mathrm{W}$ \\
\hline SD_Vsp3 (BRO-114) & Tillandsioideae & Simão Dias & $10^{\circ} 35^{\prime} 2.00^{\prime \prime} \mathrm{S}$ & $37^{\circ} 34^{\prime} 4.00^{\prime \prime} \mathrm{W}$ \\
\hline SD_Vsp4 (BRO-115) & Tillandsioideae & Simão Dias & $10^{\circ} 35^{\prime} 3.40^{\prime \prime} \mathrm{S}$ & $37^{\circ} 34^{\prime} 2.20^{\prime \prime} \mathrm{W}$ \\
\hline SD_Vsp5 (BRO-117) & Tillandsioideae & Simão Dias & $10^{\circ} 35^{\prime} 1.00^{\prime \prime} \mathrm{S}$ & $37^{\circ} 34^{\prime} 1.40^{\prime \prime} \mathrm{W}$ \\
\hline PR_Aaquilega (BRO-118) & Bromelioideae & Poço Redondo & $10^{\circ} 45^{\prime} 26.3^{\prime \prime} \mathrm{S}$ & $37^{\circ} 20^{\prime} 29.8^{\prime \prime} \mathrm{W}$ \\
\hline SD_Tpolistachia(BRO-119) & Tillandsioideae & Simão Dias & $10^{\circ} 35^{\prime} 1.40^{\prime \prime} \mathrm{S}$ & $37^{\circ} 34^{\prime} 2.00^{\prime \prime} \mathrm{W}$ \\
\hline SD_Asp2 (BRO-121) & Bromelioideae & Simão Dias & $10^{\circ} 42^{\prime} 40.1^{\prime \prime} \mathrm{S}$ & $37^{\circ} 49^{\prime} 51.5^{\prime \prime} \mathrm{W}$ \\
\hline FP_Ttenuifolia (BRO-122) & Tillandsioideae & Frei Paulo & $10^{\circ} 45^{\prime} 39.8^{\prime \prime} \mathrm{S}$ & $37^{\circ} 20^{\prime} 24.4^{\prime \prime} \mathrm{W}$ \\
\hline FP_Tbulbosa1 (BRO-123) & Tillandsioideae & Frei Paulo & $10^{\circ} 45^{\prime} 52.9^{\prime \prime} \mathrm{S}$ & $37^{\circ} 20^{\prime} 18.5^{\prime \prime} \mathrm{W}$ \\
\hline FP_Tbulbosa2 (BRO-124) & Tillandsioideae & Frei Paulo & $10^{\circ} 45^{\prime} 53,6^{\prime \prime} \mathrm{S}$ & $37^{\circ} 20^{\prime} 19.2^{\prime \prime} \mathrm{W}$ \\
\hline FP_Tlinearis (BRO-125) & Tillandsioideae & Frei Paulo & $10^{\circ} 45^{\prime} 39.8^{\prime \prime} \mathrm{S}$ & $37^{\circ} 20^{\prime} 24.4^{\prime \prime} \mathrm{W}$ \\
\hline FP_Tpolistachia1(BRO-126) & Tillandsioideae & Frei Paulo & $10^{\circ} 45^{\prime} 53.6^{\prime \prime} \mathrm{S}$ & $37^{\circ} 20^{\prime} 19.2^{\prime \prime} \mathrm{W}$ \\
\hline FP_Tpolistachia2(BRO-131) & Tillandsioideae & Frei Paulo & $10^{\circ} 45^{\prime} 52.9^{\prime \prime} \mathrm{S}$ & $37^{\circ} 20^{\prime} 18.5^{\prime \prime} \mathrm{W}$ \\
\hline
\end{tabular}

Table 4. Bromeliad accessions identified: subfamily, genus, and number of accessions.

\begin{tabular}{llr}
\hline Subfamily & Genus & Number of accessions \\
\hline Bromeliodeae & Aechemea & 10 \\
Tillandsioideae & Tillandsia & 13 \\
Tillandsioideae & Vriesea & 11 \\
\hline
\end{tabular}

The relationship between the number of fragments analyzed and the coefficient of variation was directly proportional (Figure 2). The coefficient of variation was stabilized in less than $5 \%$, suggesting that the results obtained by the fragments used in this study were suitable for analyzing diversity.

Accessions were clustered by unweighted pair group method with arithmetic mean using Jaccard similarity estimated from the binary data of 34 genotypes (Figure 3 ). The distribution of accessions in the clusters revealed the separation of different species, as well as the high divergence of some accessions. For the genus Vriesea, the analyses indicated the presence of 5 groups. Jaccard coefficients (JCs) ranged from 0.23 (SD_Vsp3 and SD_Vsp4) to 0.01 (SD_Vsp4 and I_Vsp5). We obtained subgroups that included the accessions SD Vsp3 and SD_Vsp4, which were both predicted to be in Simão Dias (Figure 3). In the genus Aechmea, JCs ranged from 0.41 (I_Amultiflora1 and I_Amultiflora2) to 0.01 (I_Anudicaulis2 
and I_Amultiflora1), and we identified 5 groups and 1 subgroup. I_Amultiflora3 was grouped with multiflora (multiflora1 and multiflora2). The 3 accessions identified as A. nudicaulis and collected in Itabaiana were placed into different groups. Accession I_Anudicaulis3 was grouped with accession SD_Asp1, suggesting that both accessions belong to the species $A$. nudicaulis (Figure 4). For the genus Tillandsia, the JCs ranged from 0.33 (I_Tgardineri and I_Tpolystachia2). The analyses revealed that accession FP_Tbulbosa2 showed similarity to 2 groups. The first group consisted of 5 accessions collected in Itabaiana (Semiarid B'sh; $188 \mathrm{~m}$ altitude) and 1 accession from Frei Paulo (Semiarid B'sh; $272 \mathrm{~m}$ altitude). The second group consisted only of accessions collected in Frei Paulo (Figure 5).

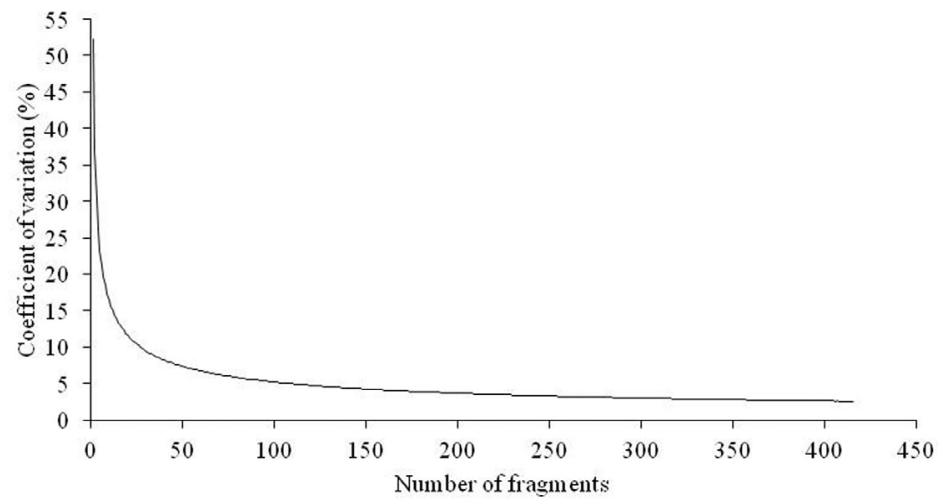

Figure 2. Coefficient of variation (\%) of the polymorphic fragments calculated by bootstrap analysis (5000X) with the Dboot software (Coelho, 2002), using inter-simple sequence repeats (ISSR) and random amplified polymorphic DNA (RAPD) markers for 34 bromeliad accessions collected in the Sergipe State.

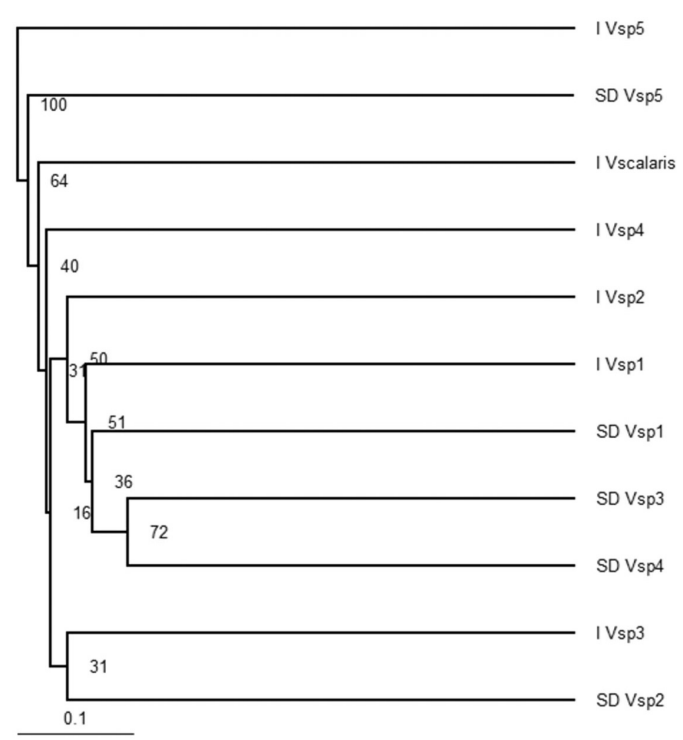

Figure 3. Dendrogram generated using the unweighted pair group method with arithmetic mean based on the Jaccard similarity matrix by combining the ISSR and RAPD primers for the genus Vriesea. 


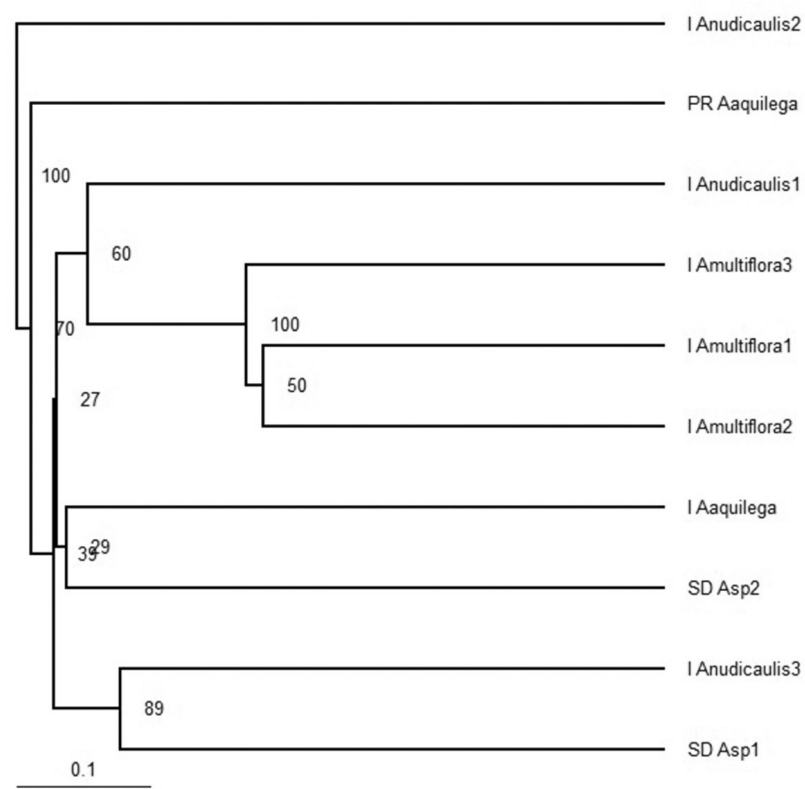

Figure 4. Dendrogram generated using the unweighted pair group method with arithmetic mean based on the Jaccard similarity matrix by combining the ISSR and RAPD primers for the genus Aechemea.

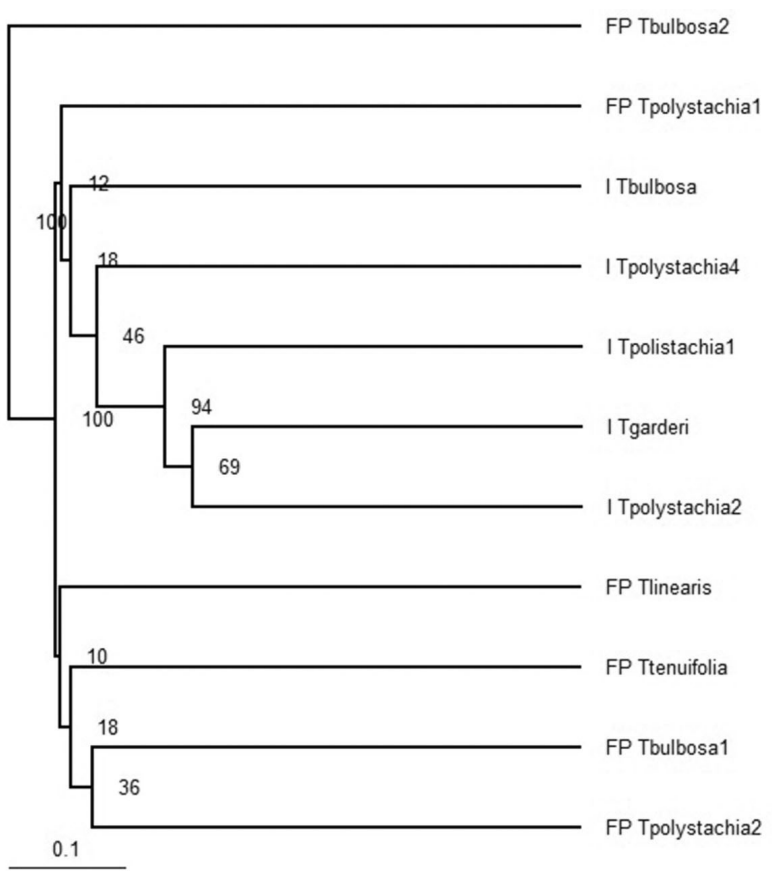

Figure 5. Dendrogram generated using the unweighted pair group method with arithmetic mean based on the Jaccard similarity matrix by combining the ISSR and RAPD primers for the genus Tyllandsia. 
Based on the dendrogram, the (JCs ranged from 0.31 (FP_Ttenulifolial and I Tpolystachia5) to 0.01 (I_Anudicaulis2 and I_Amultiflora1). The accession I_Vscalari1 it was grouped with I_Tgardineri1, and both were collected in Itabaiana (Semiarid B'sh; 188 $\mathrm{m}$ altitude). These accessions were placed in a subgroup with SD_Vsp1 and I_Amultiflora3. The accessions I_multiflora2, SD_Vsp4, I_Vsp4, and I_Tpolystachia2 formed a subgroup, of which only accession SD_Vsp4 was not collected in Itabaiana (Figure 6).

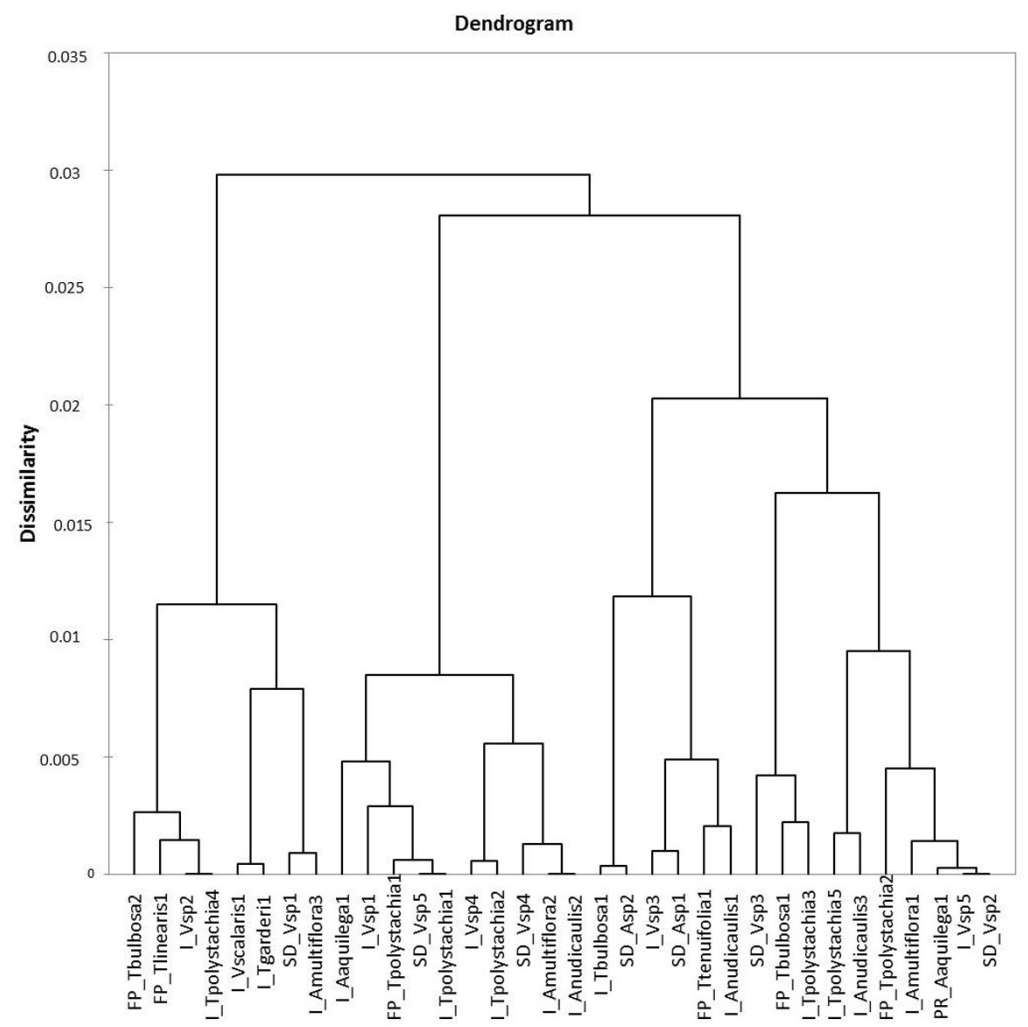

Figure 6. Dendrogram generated using the unweighted pair group method with arithmetic mean based on the Jaccard similarity matrix by combining the ISSR and RAPD primers for all 34 bromeliad accessions.

\section{DISCUSSION}

Previous studies have reported that DNA fingerprinting techniques, in combination with ISSR and RAPD, are usefulfor genotypediscrimination and for genetic similarity analysis (Fernández et al., 2002; Pinheiro et al., 2012).

The number of polymorphisms identified in our study was higher compared to other studies. In cultivars from China, only 12 ISSR markers were used, and 342 fragments from 40 bromeliad accessions were obtained (Zhang et al., 2012). In other ornamental families, Wang et al. (2009) used 25 ISSR primers to analyze the molecular diversity of 50 cultivars of Cymbidium goeringii and produced 224 fragments (94\% polymorphic). Niknejad et al. (2009) examined the molecular traits and phylogenetic relationships among orchid species of the 
Phalaenopsis genus using 10 RAPD markers, producing a total of 414 polymorphic fragments and an average of 41.4 fragments per primer; our study showed lower value, with an average of 17 fragments per primer. Both ISSR primers and PCR revealed the highest polymorphisms $(100 \%)$, while ISSR showed a greater number of fragments per primer (33.6) compared to RAPD (4.0).

In this study, we observed a large amount of diversity among bromeliad species in Sergipe State. The combined dataset from the markers facilitated the identification and separation of bromeliad accessions of the active germplasm bank, which were taxonomically placed in genera. Therefore, RAPD and ISSR profiling were efficient and useful for identifying moderate genetic divergence among the accessions pre-classified in a genus. Our results suggest that RAPD and ISSR markers are useful for taxonomic characterization of bromeliads at an early stage, even before the development of floral structures.

\section{ACKNOWLEDGMENTS}

The authors thank CNPq (Conselho Nacional de Desenvolvimento Científico e Tecnológico), FAPEMIG (Fundação de Amparo à Pesquisa do Estado de Minas Gerais), and CAPES (Coordenação de Aperfeiçoamento de Pessoal de Nível Superior) for their financial support of this study. The authors also thank the bromeliad specialists Maria das Graças L. Wanderley (Botanical Institute of São Paulo) and Gardene Maria de Sousa (Federal University of Piauí) for identifying bromeliad species.

\section{REFERENCES}

Benzing DH (2000). Bromeliaceae: Profile of Adaptive Radiation. Cambridge University Press, Cambridge.

Carvalho MA and Quesenberry KH (2009). Morphological characterization of the USA Arachis pintoi Krap. and Greg. Collection. Plant Syst. Evol. 277: 1-11.

Coelho ASG (2000). "Software" DBOOT - Avaliação dos Erros Associados a Estimativas de Distâncias/Similaridades Genéticas Através do Procedimento de Botstrap com Número Variável de Marcadores. V. 1.1. Universidade Federal de Goiás, Goiânia.

Coffani-Nunes JV (2002). Bromélias. In: Sustentável Mata Atlântica - A Exploração de Recursos Vegetais (Simões LL and Lino CF, eds.). Senac, São Paulo, 119-132.

Fernandez E, Figueiras M and Benito C (2002). The use of ISSR and RAPD markers for detecting DNA polymorphism, genotype identification and genetic diversity among barley cultivars with known origin. Theor. Appl. Genet. 104: 845-851.

Hampl V, Pavlicek A and Flegr J (2001). Construction and bootstrap analysis of DNA fingerprinting-based phylogenetic trees with the freeware program FreeTree: application to trichomonad parasites. Int. J. Syst. Evol. Microbiol. 51: 731-735.

Handa T (1998). Utilization of molecular markers for ornamental plants. J. Jpn. Soc. Hortic. Sci. 67: 1197-1199.

Luther HE (2008). An Alphabetical List of Bromeliad Binomials. The International Bromeliad Society, Sarasota.

Morales EV, Monteiro JS, Mendes RA and Fonseca JNL (1996). Conservación de Germoplasma Vegetal. Juan P. Pulgnau, IICA-PROCISUR.

Niknejad A, Kadir MA, Kadzimin SB, Abdullah NAP, et al. (2009). Molecular characterization and phylogenetic relationships among and within species of Phalaenopsis (Epidendroideae: Orchidacheae) based on RAPD analysis. Afr. J. Biotechnol. 8: 5225-5240.

Page RDM (1996). Treeview: An application to display phylogenetic trees on personal computers. Comput. Appl. Biosci. 12: 357-358.

Pinheiro LR, Rabbani ARC, Silva AVC, Silva Lédo A, et al. (2012). Genetic diversity and population structure in the Brazilian Cattleya labiata (Orchidaceae) using RAPD and ISSR markers. Plant Syst. Evol. 298: 1815-1825.

Sheng Y, Zheng W, Pei K and Keping MA (2005). Genetic variation with and among populations of a dominant desert tree Haloxylon ammodendron (Amaranthaceae) in China. Ann. Bot. 96: 245-252. 
Wang HZ, Wu ZX, Lu JJ, Shi NN, et al. (2009). Molecular diversity and relationships among Cymbidium goeringii cultivars based on inter-simple sequence repeat (ISSR) markers. Genetica 136: 391-399.

Zhang F, Ge Y, Wang W, Yu X, et al. (2012). Molecular characterization of cultivated bromeliad accessions with intersimple sequence repeat (ISSR) markers. Int. J. Mol. Sci. 13: 6040-6052. 